Animal Health Research Institute,

Shalatin Regional lab.

\title{
SARCOCYSTIS INFECTION IN SHEEP AND GOATS SLAUGHTERED IN SHALATIN ABATTOIR, RED SEA GOVERNORATE, EGYPT
}

(With 7 Tables and 2 Plates)

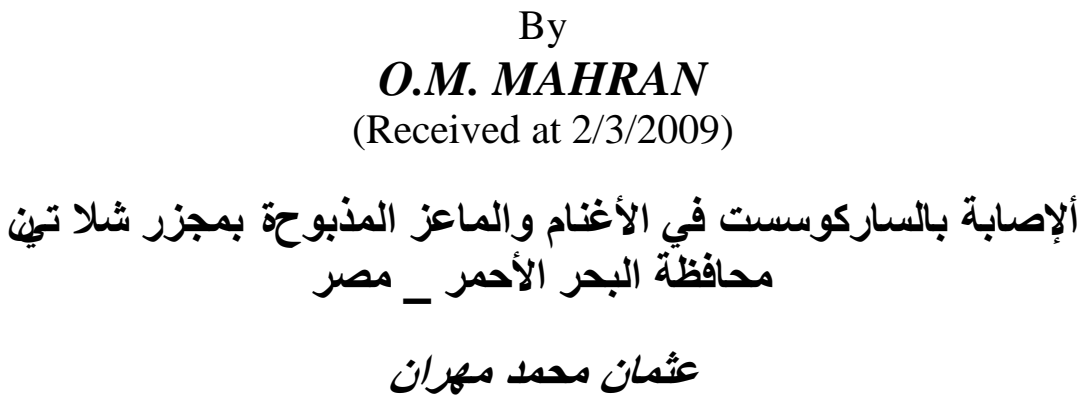

تم جمع عينات نسيجية شعلتَُّ كلا من المرئ، الحجاب الحاجز ، اللسان، القلب و العضلات بين الضلوع مِنْ 555 من الأغنام و 371 من الماعز

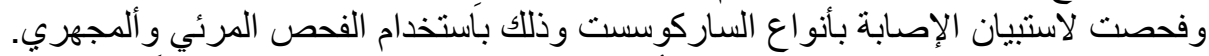

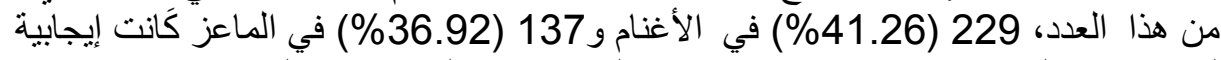
لحويصلات الساركوسست . ووجدت كلا من الحويصلات المرئي ة

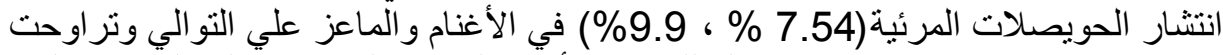

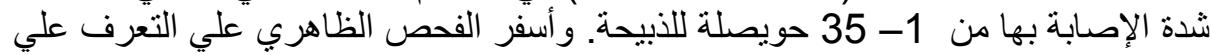

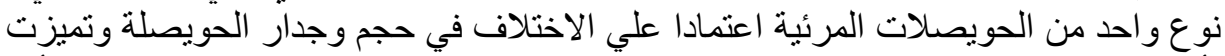

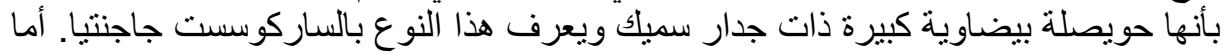

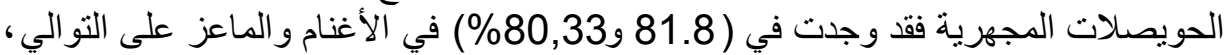

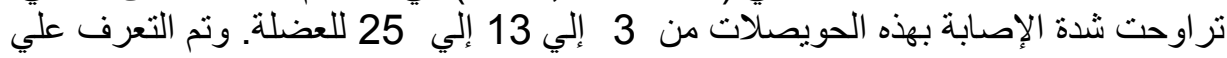
نوعين من الحويصلات المرئية اعتمادا علي الاختلاف في شكل جدار الإن الحويصلة

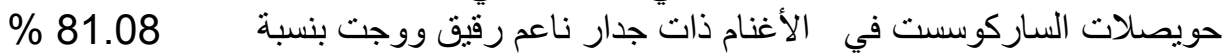

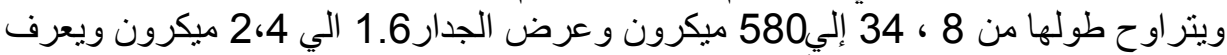

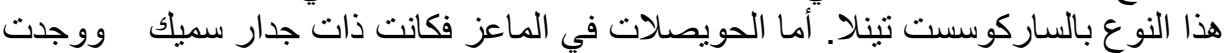

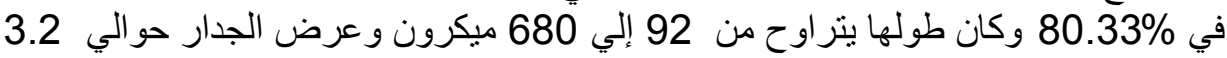

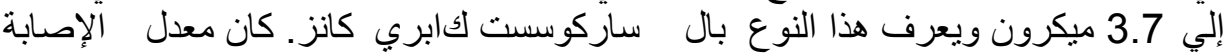

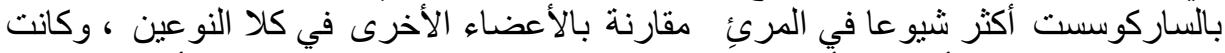

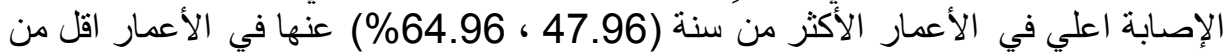

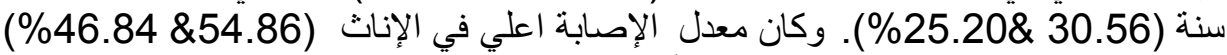

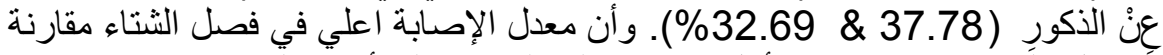

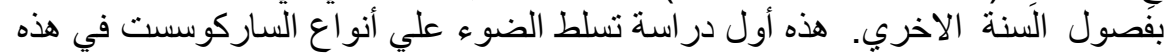




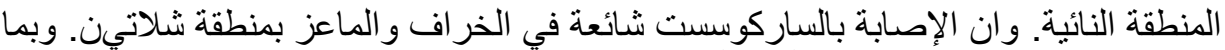

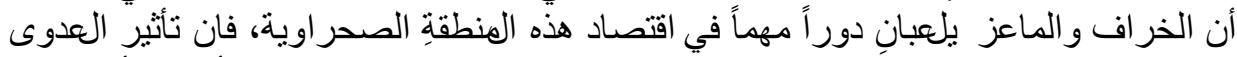

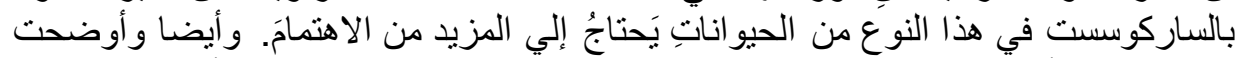

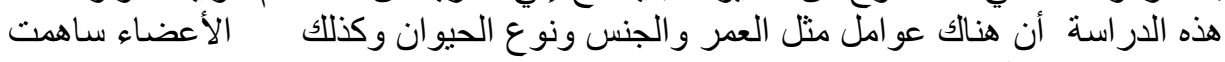
بوضوح في معدل الإصابة.

\section{SUMMARY}

Tissue samples comprising the oesophagus, diaphragm, tongue, heart and intercostal muscles were collected from 555 sheep and 371 goats slaughtered at the abattoirs in the study area. and examined for infections with Sarcocystis spp. using macroscopic and microscopic methods of detection. Out of this number, 229 (41.26\%) were positive for Sarcocystis cysts in sheep and 137(36.92\%) in Goats. Macroscopic and microscopic sarcocysts were seen. Macroscopic cysts were found in $(9.9 \% \& 7.54 \%)$ of the sheep and goats respectively, ranging in intensity from 1 to 35 cysts per carcass. Morphometric studies detected one type of macroscopic cysts which differed in their size and cyst wall morphology. Large ovoid cysts have thick primary cyst walls were identified as S. gigantea (syn. S. ovifelis). In comparison, microscopic cysts were detected in $(81.8 \%$ to $\% 80.33 \%)$ in sheep and goats respectively. Calculations of the intensities of infection ranged from 3 to 13 to 25 cysts per unit volume of muscle. Sarcocysts in sheep have smooth thin walls, measured 34.8 to $580 \mu$ lengthwise and the cyst-wall 1.6- $2.4 \mu$ They were identified to be Sarcocystis tenella (S. ovicanis). The cysts in goats measured 92 to $680 \mu$ and the cyst - wall $2.3-3.7 \mu$. They were identified as Sarcocystis capracanis. In both animal species, the sarcocysts were more frequent in the oesophagus compared to the other organs. Animals more than a year old were infested more frequently (46.96 \& 47.96\%) than those younger than a year old (30.56 $\& 25.20 \%$ ). The females had a higher rate of infestation (54.86 \& $46.84 \%)$ than males $(37.78 \& 32.69 \%)$. Infection reached peak in winter season compared to other seasons. This is the first study to throw light upon Sarcocystis species of sheep and goats in this area. Sarcocystis infection was shown to be common in sheep and goats in Shalatin area. Since the sheep and goats play an important role in the economy of this desert area. The impact of Sarcocystis infection in these animal species needs further attention. Also, this study shows that factors such as age, gender, animal type and involved organ contribute to the frequency infestations. 
Key words: Sarcocystis sheep, goats at Shalatin

\section{INTRODUCTION}

Sarcocystis infections of animals are commonplace and of worldwide distribution. Some species can be severely pathogenic to farm animals, causing anorexia, weight-loss, abortion and even death. But perhaps because sarcocysts are so common they have frequently been regarded as innocuous. Many cases of abortion in farm animals go undiagnosed, and it is only now that Sarcocystosis is being implicated as potentially of economic importance to the farm industry (Dubey et al., 1988). In many cases however, the major effect is likely to be subclincal, seen in farm animals only as a reduction in live weight gain (Herbert and Smith, 1987). Sarcocystosis is a zoontic disease in domestic animals caused by Sarcocystis spp., a cyst-forming coccidian parasite with obligatory two-host life cycle involving carnivorous as definitive hosts and herbivorous or omnivorous as intermediate hosts. Each intermediate and definitive host may harbor more than one Sarcocystis species (Dubey et al., 1989). Some species of Sarcocystis can cause a reduced weight gain, poor feeding efficiency, anorexia, fever, anemia, muscle weakness, reduced milk yield, abortion, and death of intermediate hosts such as cattle, sheep and goats. Anemia, anorexia, ataxia, and abortions are the chief clinical signs of acute ovine sarcocystosis (Dubey, 1976). Certain species can infect humans and can cause digestive disturbances such as nausea vomiting, and diarrhea (Rommel, 1989). Recent studies, however, have shown that muscular Sarcocystosis is a bigger problem than previously thought. (Dubey et al., 1989). Sarcocystis is found mainly in striated muscles where it causes myositis, degenerative changes, atrophy and death in their hosts (Levine, 1986). (Harness et al., 1999) mentioned that infection of the intermediate host causes a loss of appetite, fever, weight loss, anemia, and death in severe infections. It also causes gait abnormalities, weakening of the limbs, muscle wasting, and head tilt. The animal may also move in circles. The number of clinical signs that appear is proportional to the number of Sarcocystis organisms parasitizing the host (Dubey et al., 1988). Humans might become accidental intermediate hosts for a number of species of Sarcocystis (S. bovihominis and S. suilhominis) and the infection is acquired in human by eating insufficiently cooked meat. This work presents the results of the first study on the prevalence of Sarcocystis infection in this remote area in sheep and goats, identify the species and 
describe the morphological characters, besides the influence of age, gender and seasons on the infection rate of Sarcocystis was also studied.

\section{MATERIALS and METHODS}

\section{Animals}

During December 2007 to November 2008 a total of 926 animals comprised of 555 sheep and 371 goats belonging to both gender and different ages slaughtered at Shalatin abattoir were investigated for the presence of Sarcocystis in muscular tissues. Age and gender of the Investigated animals were assessed by visual inspection of teeth, horns, and sexual organs.

\section{Samples:}

The oesophagus, diaphragm, tongue, heart and intercostal muscles were chosen for inspection and collection of samples, immediately after the animals were slaughtered, the freshy tissues were labeled separately, put in ice box, brought to the laboratory and were kept at $4^{\circ} \mathrm{C}$ until further examination.

Macroscopical examination: each sample was examined by naked eye for detection of macroscopic cysts. Oesophagus was thoroughly washed in running tap water to expel the ingesta present in the lumen. The superficial, fat and connective tissue were removed. Each oesophagus was thoroughly searched for the presence of (Macro cysts) in the musculature. Special effort was made to detect the small-sized sarcocysts that might have been embedded deeply in the tissue by ballooning out the oesophagus by filling it with water and then examining against a strong light (Saleque et al., 1992).

Microscopical examination: the samples found negative on gross examination were examined microscopically by 1 - crush technique: About $2 \mathrm{~g}$ of tissue was cut into small pieces, approximately $3-5 \mathrm{~mm}$ thick, and crushed firmly between two glass slides and examined under the microscope $(40 \mathrm{x})$ (Mohanty et al., 1995). For detection of liberated trophozoites: homogenization of muscle samples was done with physiological saline (Ali, 1985). The intensity of infection in muscles from different parts of individual animals was recorded as number of microcysts present in $2 \mathrm{~g}$ of muscles examined. The intensity of infection was considered as light $(+)$, moderate $(++)$ and heavy (+++) depending upon the presence of 1-10 cysts, 11-20 cysts and 20 or more cysts per $2 \mathrm{~g}$ of muscles respectively (Dayashank and Bhatia, 1993). 
Histomorphlogical examination: muscular samples sized approximately $15 \mathrm{~mm} \times 10 \mathrm{~mm}$ with or without macroscopically visible sarcocysts were cut from each of the muscular tissues mentioned. The samples were fixed in neutral buffered $10 \%$ formalin, processed by standard histological techniques, sectioned at $5 \mathrm{~mm}$, stained by haematoxylin and eosin, and examined by light microscopy for the presence of sarcocysts, (Bancroft and Stevens, 1993). The differentiation between the microscopic species was based on the morphological criteria described by (Levine, 1985) and (Dubey et al., 1989)

\section{RESULTS}

Combination of ocular and histological examination revealed that $229(41.26 \%)$ of 555 sheep and $137(36.92 \%)$ of 371 goats had sarcocysts of at least one species described in sheep and goats (Tables 1 $\& 2$ ). The prevalence of macroscopic and microscopic sarcocysts in slaughtered sheep and goats, is shown in table (2). Macroscopic cysts were found in $(9.9 \%$ to $7.54 \%)$ of sheep and goats respectively. Morphometric studies detected one type of macroscopic cysts which differed in their size and cyst wall morphology. Cysts appeared as large ovoid cysts with thick primary cyst walls, milky-white colored embedded in the muscular tissues and their length ranged from 4 to $6 \mathrm{~mm}$, ranging in intensity from 1 to 35 cysts per carcass. They were identified as S. gigantea (syn. S. ovifelis) plates 1 (1\&2). Microscopic cysts were detected in $81.8 \%$ to $80.33 \%$ in sheep and goats respectively. Calculations of the intensities of infection ranged from 3 to 13 to, 25 cysts per unit volume of muscle. Two types of microscopic cysts were also identified on the basis of their cyst wall morphology. Cysts having smooth thin walls were detected in $81.8 \%$ of the sheep measured 34.8 to $580 \mu$ lengthwise and the cyst-wall 1.6- $2.4 \mu$, appeared to conform to the original descriptions of $S$. tenella (S. ovicanis) plate $2(3 \& 4)$, whereas cysts, with radially-striated thick walls were found in $80.33 \%$ of the goats measured 92 to $680 \mu$ and the cyst - wall $2.3-2.7 \mu$ appeared to conform to the original descriptions $S$. capracanis plate 2 (5). Concerning the prevalence of Sarcocystis spp. in different muscular tissues and Intensity of infection amongst positive cases in sheep and goats, oesophagus showed the highest rate $(71.17 \& 67.38)$ and heart the lowest $(38.7 \%$ \& $41.23 \%)$ in sheep and goats respectively. (tables $3 \& 4)$. In both males and females animals the prevalence of Sarcocystis infection increased with age (Tables 5\&6). Overall, the prevalence of 
infection was lowest in animals below a year old (30.56 \& 25.20) and highest in animals more than a year old (46.96 \& 47.96\%) in sheep and goats respectively. The female animals had a higher rate of infestation than males $(37.78 \%-54.86 \%)$ and $(32.69 \%-46.84 \%)$ in sheep and goats respectively (Tables 5\&6). The seasonal prevalence of sarcocysts in sheep and goats examined in the present study has been shown in (table 7). It's evident from the tables that the infection was prevalent throughout the year under study with the highest rate in winter season and lowest in summer seasons.

\section{Morphological studies:}

Macroscopic cyst: Cysts were found in (9.9\% to $7.54 \%$ ) of the sheep and goats respectively, ranging in intensity from 1 to 35 cysts per carcass. cysts found as ovoid cysts resemble, grains of rice with thick primary cyst walls as grayish to whitish streaks, in color 4-6 mm in length, running lengthwise with the muscle fibers. They were identified as $S$. gigantea (syn. S. ovifelis). A mature cyst, $350 \mu$ in length, up to 0.5 $\mathrm{mm}$ long and a secondary cyst wall was present plate(1).

\section{Microscopic cysts:}

In sheep: Cysts were detected in (81. 8\%) of sheep as cylindrical or fusiform, with tapering ends,. They consist of a delimiting membrane from which trabeculae pass inwards, and are filled with spores. The spores are more mature towards the center of the cysts. The sarcocysts measured 34.8 to $580 \mu$ lengthwise and with smooth thin cyst walls measuring1.6- $2.4 \mu$. The cystozoites in mature sarcocystis, were banana shaped and measured 13.0-15.0 um by 3.6-6.0 um in size. Such cysts were described as $S$. tenella (S. ovicanis) plate $2(3 \& 4)$.

In goats: Cysts were detected in $(80.33 \%)$. Sarcocysts showed thick wall with radial striations and finger like projections, mostly elongate, slender or spindle shaped with one or both ends tapering. The cysts in goats measured 92 to $680 \mu$ and the cyst-wall was thick measuring 2.3$2.7 \mu$. Oval metrocytes were seen measuring 7.3-11.2 $\mu \mathrm{m} \times 4.3-7.0 \mu \mathrm{m}$. Bradyzoites were banana shaped and measured 8-12.3 $\mu \mathrm{m}$ septa were seen dividing the sarcocyst cavity into a number of compartments such cyst was described as $S$. capracanis plate 2 (5). 
Table 1: Prevalence of Sarcocystis infection in sheep and goats examined 4.

\begin{tabular}{|c|c|c|c|c|c|}
\hline & \multirow{2}{*}{$\begin{array}{c}\text { No. } \\
\text { examined }\end{array}$} & \multirow{2}{*}{$\begin{array}{c}\text { No. } \\
\text { Infected animals }\end{array}$} & \multicolumn{3}{|c|}{ No. of positive\% } \\
\hline & & & $\begin{array}{c}\text { Macroscopic } \\
\text { cysts }\end{array}$ & $\begin{array}{c}\text { Microscopic } \\
\text { cysts }\end{array}$ & Mixed infection \\
\hline Sheep & 555 & $229(41.26 \%)$ & $55(9.9 \%)$ & $450(81.8 \%)$ & $55(9.9 \%)$ \\
\hline Goats & 371 & $137(36.9 \%)$ & $28(7.54 \%)$ & $298(80.33 \%)$ & $28(7.54 \%)$ \\
\hline
\end{tabular}

Table 2: Prevalence of macroscopic cysts in sheep and goats according to organs examined

\begin{tabular}{|c|c|c|c|c|c|c|}
\hline $\begin{array}{c}\text { No. of } \\
\text { Animal } \\
\text { examined }\end{array}$ & $\begin{array}{c}\text { No. Positive } \\
(\%)\end{array}$ & Esophagus & Diaphragm. & Heart & Tongue & $\begin{array}{c}\text { Intercostals } \\
\text { muscles }\end{array}$ \\
\hline Sheep (555) & $55(9.91)$ & $45(81.81)$ & $7(12.72 \%))$ & $3(5.45 \%)$ & - & - \\
\hline Goats (371) & $28(7.54)$ & $17(60.71 \%)$ & $7(25 \%)$ & $4(14.29 \%)$ & - & - \\
\hline
\end{tabular}

Table 3: Prevalence of Sarcocystis spp. in different muscular tissues of sheep $(n=555)$ and Intensity of infection amongst positive cases

\begin{tabular}{|c|c|c|c|c|c|c|}
\hline \multirow[t]{2}{*}{ Organs } & \multirow{2}{*}{$\begin{array}{c}\text { No. of } \\
\text { samples of } \\
\text { organs / } \\
\text { tissues } \\
\text { examined. }\end{array}$} & \multirow{2}{*}{$\begin{array}{l}\text { No. of } \\
\text { organs / } \\
\text { tissues } \\
\text { positive }\end{array}$} & \multirow{2}{*}{$\begin{array}{c}\text { (\%) of } S . \\
\text { tenella } \\
\text { found } \\
\text { amongst } \\
\text { positive } \\
\text { case }\end{array}$} & \multicolumn{3}{|c|}{$\begin{array}{c}\text { (Intensity of infection) average no. cysts per } 10 \\
\text { microscope fields in positive cases }\end{array}$} \\
\hline & & & & $+(\%)$ & $++(\%)$ & $+++(\%)$ \\
\hline Esophagus & 555 & 395 & 71.17 & $325(82.28 \%)$ & $40(10.13 \%)$ & $30(7.59 \%)$ \\
\hline Diaphragm & 555 & 305 & 54.95 & $260(85.25 \%)$ & $27(8.85 \%)$ & $18(5.9 \%)$ \\
\hline Heart & 555 & 205 & 36.94 & $178(86.83 \%)$ & $15(7.32 \%)$ & $12(5.85 \%)$ \\
\hline Tongue & 555 & 270 & 48.65 & $240(88.89 \%)$ & $21(7.79 \%)$ & $9(3.33 \%)$ \\
\hline $\begin{array}{c}\text { Intercostals } \\
\text { muscles }\end{array}$ & 555 & 226 & 40.72 & $201(88.94 \%)$ & $18(7.96 \%)$ & $7(3.093 \%)$ \\
\hline Total & 2775 & 1401 & 50.49 & $1204(85.94 \%)$ & $121(8.64 \%)$ & $76(5.42 \%)$ \\
\hline
\end{tabular}


Table 4: Prevalence of Sarcocystis spp. in different muscular tissues of goats $(n=371)$ and Intensity of infection amongst cases positive.

\begin{tabular}{|c|c|c|c|c|c|c|}
\hline \multirow{2}{*}{$\begin{array}{c}\text { Organs / } \\
\text { tissues } \\
\text { Examined }\end{array}$} & $\begin{array}{c}\text { No. Of } \\
\text { samples } \\
\text { organs / } \\
\text { tissues } \\
\text { examined. }\end{array}$ & $\begin{array}{c}\text { No. Of } \\
\text { organs / } \\
\text { tissues } \\
\text { positive }\end{array}$ & $\begin{array}{c}\text { S.capracanis } \\
\text { found amongst } \\
\text { positive case }\end{array}$ & \multicolumn{2}{|c|}{$\begin{array}{c}\text { (Intensity of infection) } \\
\text { average no. cysts per 10 microscope fields in } \\
\text { positive cases }\end{array}$} \\
\hline Esophagus & 371 & 250 & 67.38 & $210(84 \%)$ & $28(11.2 \%)$ & $12(4.8 \%)$ \\
\hline Diaphragm & 371 & 197 & 53.09 & $166(84.26 \%)$ & $22(11.16 \%)$ & $9(4.57 \%)$ \\
\hline Heart & 371 & 153 & 41.23 & $135(88.23 \%)$ & $12(7.84 \%)$ & $6(3.92 \%)$ \\
\hline $\begin{array}{c}\text { Tongue } \\
\text { Intercostals } \\
\text { Muscles }\end{array}$ & 371 & 185 & 49.87 & $162(87.57 \%)$ & $16(8.65 \%)$ & $7(3.78 \%)$ \\
\hline Total & 1855 & 170 & 45.82 & $146(85.88 \%)$ & $16(9.41)$ & $8(4.7 \%)$ \\
\hline
\end{tabular}

Table 5: Distribution of sheep infected with $S$. tenella according to age and gender at Shalatin area.

\begin{tabular}{|l|l|c|c|c|}
\hline Gender & Animal examined & Below one year & Above one year & Total \\
\hline Male & No. Exam. & 145 & 297 & 442 \\
& No. Positive & 40 & 127 & 167 \\
& Percentage & 27.58 & 42.76 & 37.78 \\
\hline Female & No. Exam. & 48 & 65 & 113 \\
& No. Positive & 19 & 43 & 62 \\
& Percentage & 39.58 & 66.15 & 54.86 \\
\hline Total & No. Exam & 193 & 362 & 555 \\
& No. Positive & 59 & 170 & 229 \\
& Percentage & 30.56 & 46.96 & 41.26 \\
\hline
\end{tabular}

Table 6: Distribution of goats infected with S. capracanis according to age and gender at Shalatin area.

\begin{tabular}{|c|c|c|c|c|}
\hline Gender & Animal examined & Below one year & Above one year & Total \\
\hline Male & No. Exam. & 75 & 185 & 260 \\
& No. Positive & 14 & 71 & 85 \\
& Percentage & 18.66 & 38.37 & 32.69 \\
\hline Female & No. Exam. & 48 & 63 & 111 \\
& No. Positive & 17 & 35 & 52 \\
& Percentage & 35.41 & 55.55 & 46.84 \\
& No. Exam. & 123 & 482 & 371 \\
\hline Total & No. Positive & 31 & 106 & 137 \\
& Percentage & 25.20 & 42.74 & 36.92 \\
\hline
\end{tabular}


Table 7: Seasonal variation of Sarcocystis infections in sheep and goats

\begin{tabular}{|l|c|c|c|c|c|c|}
\hline Seasons & \multicolumn{2}{|l|}{$\begin{array}{l}\text { No. Of } \\
\text { Animals }\end{array}$} & exam. & \multicolumn{2}{l|}{ No. Of infected cases } & \multicolumn{2}{l|}{ Percentage of infection } \\
\cline { 2 - 7 } & Sheep & Goats & Sheep & Goats & Sheep & Goats \\
\hline Winter & 165 & 121 & 95 & 58 & 57.57 & 47.93 \\
\hline Spring & 146 & 94 & 60 & 37 & 41.09 & 39.36 \\
\hline Summer & 116 & 81 & 38 & 17 & 32.75 & 20.98 \\
\hline Autumn & 128 & 75 & 36 & 25 & 28.12 & 33.3 \\
\hline Total & 555 & 371 & 229 & 137 & 41.26 & 36.92 \\
\hline
\end{tabular}

Plate 1: Morphological characters of visible sarcocysts

1- Grossly visible sarcocysts the oesophagus muscle of sheep.

2- Grossly visible sarcocysts in heart muscle of goats 
Plate 2: Morphological character and structure of Sarcocystis tenella and S. capracanis

3- Microphotograph of sarcocysts of Sarcocystis tenella from muscles of sheep $(\mathrm{H} \& \mathrm{E} \times 10)$.

4- Microphotograph of sarcocysts of Sarcocystis tenella from muscles of sheep showing smooth cyst thin walls and spores are more mature towards the center of the cysts. $(\mathrm{H} \& \mathrm{E} \times 40)$.

5- Microphotograph of sarcocysts of Sarcocystis caparacanis from muscles of goats showing septa and thick cyst wall (H\&E $\times 1000)$.

\section{DISCUSSION}

The current study revealed that $(41.26 \%)$ and $(36.92 \%)$ out of 555 sheep and 371 goats carcasses screened carried Sarcocystis infection respectively, this is compatible with the report of (Saha and Ghosh,1992) and (Abo- Shehada, 1996) in Jordan. Our results was lower than that recorded by Dubey et al. (1989) in United States, Latif et al. (1999) in 
Iraq and Nedjari (2003) in Algeria who reported that the rate of infection was (91.6\%), (100\%), (97-97.4\%) and (64\%) in sheep and goats respectively. The difference in prevalence rate of sarcocysts might be due to different factors like discontinuation of life cycle, management condition, living of stray dogs and cats with livestock and habits of definitive and intermediate hosts (Masoud et al., 2007). In the present study macro-sarcocysts and micro- sarcocysts were encountered in sheep and goats, agreeing with Abo-Shehada (1996) in Jordan, Latif et al. (1999) and Barham et al. (2005) in Iraq, Al- Hoot et al. (2005) in Saudi Arabia and Daryani et al. (2006) in Iran. disagreeing with the finding of Pethkar and Shah (1983), Hussein and Warraq (1985), Kudi et al. (1991) and Mohanty et al. (1995), who reported micros-sarcocysts only. The high prevalence rate of microscopic sarcocysts $(81.08 \%$ \& $80.32 \%)$ in sheep and goats indicates the importance of the infection for the intermediate host. Fayer and Dubey (1986) reported that the rate of infection with micro-sarcocysts reached $100 \%$ in sheep in the United States and Ginawi and Shommein (1977) in Sudan reported (91.6\%) in goats. The low frequency of macroscopic sarcocysts $(9.9 \& 7.54 \%)$ in the present study, compared with the prevalence of microscopic sarcocysts $(81.08 \%$ \& $80.32 \%)$ may be due to the fact that such cysts are of feline origin and the contact between farm animals and cats is rare as the farmers do not keep cats Latif et al. (1999) in Iraq and Al-Hoot et al. (2005) in Saudi Arabia reported low incidence of macroscopic cysts compared with microscopic cysts was between (0-33.6\%) in Iraq and (8 to $18 \%$ ) and (73 to $85 \%$ ) in Saudia Arabia. Two types of microsarcocysts were differentiated on the basis of their morphology Sarcocystis tenella in sheep and S. capracanis in goats. S. tenella is thought to be the most pathogenic of the Sarcocystis species in sheep. It can cause anorexia, fever, decreased weight gain, anemia and death in experimentally infected lambs, and has been associated with abortions in ewes. Neurologic signs including encephalomyelitis, muscle weakness, hind limb paresis and ataxia have been seen in naturally infected sheep. After recovery from the acute illness, some sheep may lose their wool. Acute deaths can also occur without other symptoms (Fayer and Dubey, 1986). Macroscopic sarcocysts of S. gigantea were also found in sheep and goats. This is compatible with the report of Dubey et al. (1989), Abo-Shehada (1996) in Jordan, Latif et al. (1999) and Barham et al. (2005) in Iraq and Al- Hoot et al. (2005) in Saudi Arabia. The morphology of Sarcocystis species in the present study, was comparable to the description given by Munday and Obendorf (1984), Odonoghue 
and Ford (1986), Dayashank and Bhatia (1993) and Dubey et al. (1988). Concerning the prevalence of Sarcocystis spp. in different muscular tissues and intensity of infection amongst positive cases in sheep and goats tables ( $3 \& 4)$ revealed that maximum sarcocysts were found in the muscles of oesophagus in sheep and goats. Saha and Ghosh (1992), Huong and Uggla (1999), Latif et al. (1999) and Jumde et al. (2000) made similar observation. Oesophagus musculature appeared as more favorable site of Sarcocystis infection Fayer and Dubey (1986). The severity of clinical signs that appear is proportional to the number of Sarcocystis cysts parasitizing the host (Dubey et al., 1989). Our study revealed a heavy intensity of Sarcocystis species in the muscles of oesophagus followed by those in diaphragm, tongue, intercostal muscles and heart. Fewer reports on this aspect were recorded by Shastri (1990) who counted (67) cysts in $20 \mathrm{~g}$ of a muscle piece of diaphragm and Dayashank and Bhatia (1993) recorded highest number of cysts in $2 \mathrm{~g}$ of a muscles pieces of oesophagus and diaphragm. In the present study, there was a seasonal variation in percentage of positive cases reaching the peak in winter and lowest in Summer. The high incidence in winter may be due to the high humidity and easy dissemination of sporocysts shed by definitive host. Humidity is favorable for the spread and survival of sporocysts and there are more chances of contamination of food and water (Masoud et al., 2007). The low prevalence of positive cases in Summer seasons may be attributed mainly to the high temperature and reduced humidity preventing the dissemination of sporocysts by drying the feaces (Mohanty et al., 1995). These results agree with the results of Pethkar and Shah, (1983) and Singip et al. (1992) who recorded that the highest rate of positive cases was found in Winter and lowest in Summer, disagreeing with the finding of Talari et al. (2003) who reported that seasons of the year have no influence on the percentage of infection. The season -wise incidence of sarcocystis varied from place to place as it mainly depended upon the geoclimatic condition of the region and close proximity between definitive host and intermediate host (Singip et al., 1992). The incidence of infection was found to increase with age. The overall prevalence of Sarcocystis was the lowest in animals below a year old and highest in above a year old, thereby indicating a positive correlation between the prevalence rate and age of animals, which may be explained by the fact that the adults pick up over a long period and more exposure to infective grazing field (Mohanty et al., 1995) whereas the younger animals remain mostly confined to the shed and thus do not get more chances to pick up infection, also younger 
animals usually are not sent for grazing they may remain with their mother and are sometimes stall-feed up to 2 months of age. Biswas et al. (1990), Mohanty et al. (1995) and Abo-Shehada (1996), observed that higher incidence of infection was recorded in older animals and lower prevalence in younger animals. Observation on the variation due to gender on prevalence of sarcocysts infection in sheep and goats indicated that the incidence was comparatively higher in females than in males, which correlates with the observation of Rommel (1985) and Mohanty et al. (1995).

\section{REFERENCES}

Abo-Shehada M.N., (1996): Age variations in the prevalence of sarcocystosis in sheep and goats from northern and central Jordan. Prev. Vet. Med. 27: 135-140.

Al-Hoot, A.S.; Al-Qureishy, S.A.; Al-Rashid, K. and Bashtar, A.R. (2005): Microscopic study on Sarcocystis moulei from sheep and goats in Saudi Arabia. Journal of the Egyptian Soci. of Parasitol. 35: (1) 295-312

Ali, G.A.T. (1985): Studies on Sarcocystis of animals in Assiut Governorate. M.V.sc. Thesis, Fac. of Vet. Med., Assiut Univ.

Bancroft, J.D. and Stevens, A. (1993): Theory and practice of Histological Techniques, 3rd Ed. Long Man Group Limited.

Barham, M.; Sttzer, H.; Karnnis, P.; Latif, B.M. and Neiss, W.F. (2005): Seasonal variation in Sarcocystis species infections in goats in Northern Iraq. Parasitol., 130: 151-156.

Biswas, S.; Chakrabarti, A. and Roy, S. (1990): Sarcocystis infection in buffalo meat (Carabeef) in West Bengal. J. Vet. Anim. Sci., 21, 29-31.

Daryani, A.; Alaei, R.; Dehghan, M.H.; Arab, R.; Sharif, M. and Ziaei, $H$. (2006): Survey of Sarcocystis Infection in Slaughtered sheep and Buffaloes in Ardabil, Iran. Journal of Animal and Veterinary Advances 5 (1): 60-62.

Dayashank, A.R. and Bhatia, B.B. (1993): Sarcocystis infection in goats in Uttar Pradesh. Indian J. of animal Sci, 63 (3) 248- 287.

Dubey, J.B. (1976): A review of Sarcocystis of domestic animals and other coccidians of cats and dogs J. Am. Vet. Med. Assoc. 15169 (10): 1061-78. 
Dubey, J.P.; Lindasy, D.S.; Speer, C.A.; Fayer, R. and Livingston. C. W. (1988): Sarcocystis rieticanis and other Sarcocystis species in sheep in the United States. J. Parasitol. 74(6): 1033-1038.

Dubey, J.P.; Speer, C.A. and Fayer, R. (Eds.). (1989): Sarcocystosis of Animals and Man. CRC Press, Inc., Florida, Trop. Anim. Health Prod. (215). 62-78.

Fayer, R. and Dubey, J.P. (1986): Bovine sarcocystosis. Com. Contin. Educ. Pract. Vet., 8:130-14

Ginawi, M.A. and Shommein, A.M. (1977): Prevalence of sarcocystosis in sheep, goats and camels in the Sudan. J. Vet. Sci. Anim. Husb. 18: 92-97.

Harness, M.K.; Brown, J.D.; Dubey, J.P.; Neafie, R.C. and Granstrom, D.E. (1999): An outbreak of acute eosinophilic myositis attributed to human Sarcocystis parasitism. Am. J. Trop. Med. Hyg., 61 (4): 548-553.

Herbert, L.V. and Smith, T.S. (1987): Sarcocystosis review. Parasitology Today.3: 16-21.

Huong, L.T.T. and Uggla, A. (1999): Sarcocystis dubeyi n. sp. Protozoa: Sarcocystidae) in the water buffalo (Bubalus bubalis). J Parasitol. 8:102-104.

Hussein, H.S. and Warraq, M. (1985): Prevalence of Sarcocystis in food animals in the Sudan. Trop. Anim. Health prod., 17(2): 100112.

Jumde, P.D.; Bhojne, G.R.; Maske, D.K. and Kotte, S.W. (2000): Prevalence of sarcocysts in goats at Nagpur. Indian J., 77: 662668.

Kudi, A.C.; Aganga, A.O.; Ogbogu, V.C. and Umoh, J.U. (1991): Prevalence of sarcocystis in sheep and goats in north Nigeria. Rev. Elev. Med. Vet... Pays trop. 44: 59-60.

Latif, B.M.A.; Al-Delemi, J.K.; Mohammed, B.S.; Al-Bayati, S.M. and Al-Amiry, A.M. (1999): Prevalence of Sarcocystis spp. in meatproducing animals in Iraq. Vet. Parasitol., 84 (1-2): 85-90

Levine, N.D. (1985): Veterinary Protozoology (1st ed.). Lowa State, University press, Ames.

Levine, N.D. (1986): The taxonomy of Sarcocystis (Protozoa, Apicomplexa) species. J. Parassitol.72: 372-382.

Masoud, G.; Hossein, H.; LilY, N.; Gholam, H.K and Mohammad, R.A. (2007): Evaluation of an Elisa for the diagnosis of Sarcocystosis in water buffaloes. Bull Vet Inst Pulawy 51: 229231. 
Mohanty, B.N.; Misra, S.C.; Panda, D.N. and Panda, M.R. (1995): prevelance of Sarcocystis infection in ruminants in Orissa. Indian Vet. 72: 1026- 1030.

Munday, B.L. and Obendorf, D.L. (1984): Morphology of Sarcocystis gigantea in experimentally-infected sheep. Vet. Parastol. 16: 192-193.

Nedjari, M. (2003): The occurrence of animal sarcocystiosis in Algeria. Berl Munch 16(3-4): 139-141.

Odonoghue, P.J. and Ford, G.E. (1986): The prevalence and intensity of Sarcocystis spp infections in sheep. Aust. Vet. J., 63 (9): 273278.

Pethkar, D.K. and Shah, H.L. (1983): Prevalence of sarcocysts in goats in Madhya Pradesh. Indian Vet. J., 59: 110-11.

Rommel M. (1985): Sarcocystosis of domestic animals and humans, In Practice, 158-160.

Rommel, M. (1989): Recent advances in the knowledge of the biology of the cyst-forming Coocidia. Angew. Parasitol., 30 (3): 173-183.

Saha, A.K. and Ghosh, D. (1992): Prevalence of Sarcocystis in black Bengal in goats in Tripura. Indian Vet. J., 69: 82-83.

Saleque, A.; Bhatia, B.B. and Dayashanker, A.R. (1992): Prevalence of two species of Sarcocystis in sheep in Uttar Pradesh.Indian Vet. J., 69: 841-842.

Shastri, U.V. (1990): Sarcocystis infection in goats in Maharashtra. Indian Vet. J., 67: 70-71.

Singip, L.A.I.; Mraisinghanf, P.M.; Pathak, K.M.L.; Dkumar, G.S.; Manohar, A.K.; Bhans, J.K.; Arora, and Swarankar, C.P. (1992): Epidemiology of Sarcocystis capracanis in goats at Bikaner, Rajasthan, India. Indian J. animal Sci. 62 (11):10441045.

Talari, S.A.; Momtazmanesh, N.; Rad, E.M. and Talari, M.R (2003):

Prevalence of Sarcosystis spp. at slaughter house of KashanIran. Uttar Pradesh J. Zool.,. 23 ( 3 ): 197-200 